\title{
QUARTERLY ANALYSIS \\ MONETARY, BANKING, AND PAYMENT \\ SYSTEM DEVELOPMENTS \\ QUARTER I - 2014
}

The Author Team of Quarterly Report, Bank Indonesia

Indonesia's economy performed an under-controlled economic stability and was sustained by the economic adjustment in quarter I 2014. During the period, inflation was in the declining trend along with smaller current account deficit. The capital inflow also increased along with the improvement of economic fundamental which in turn contributed to the appreciation of Rupiah's exchange rate. Accordingly, domestic demand was well-managed, even though the growth performed a sharp decrease and was lower than expected as the impact of real export contraction from mining sector. The development was not apart from the policy consistency taken by Bank Indonesia and the government since the mid 2013 to strengthen the economic stability and managed the growth to run proportionally and sustainably.

In the quarter I 2014, the domestic demand was well-managed, even though it experienced a slowing down growth due to real export contraction. The under-controlled domestic demand was sustained by the highly growing household consumptions, driven by consumer confidence, and the impact of legislative general election. The investment started to be sustained by nonbuilding investment that had been positively growing, while building investment had been slowing down. Nevertheless, the manageable domestic demand could not resist the slowing down economic growth, which declined lower than expected in the quarter I 2014. The slowing down economic growth was driven by the real export contraction mainly from mining commodities such as coal and mineral concentrate in the form of decreasing demand primarily from Tiongkok, decreasing prices, and also temporarily impact of banning raw materials export policy. From the regional side, the slowing down economic growth occurred in any regions sustained by mining sector which is in the Eastern Indonesia (Kawasan Indonesia Timur/KTI). The export contraction was relatively huge leading to the decrease of net export, even to some extent, import decreased along with moderating trend of domestic demand.

The manageable domestic demand sustained by the under-controlled economic stability drove the improvement of Indonesia's Balance of Payment (IBP). In the quarter I 2014, IBP recorded surplus by USD 2.07 billion sustained by the decrease of current account deficit and the increase of capital inflow. In the quarter I 2014, the current account deficit was recorded by $2.06 \%$ to GDP, decreasing from the previous deficit in the quarter IV 2013 by $2.12 \%$ to GDP. Improvement of the current account deficit was primarily driven by the decrease of balance of service deficit, especially freight services, along with the decrease of import activities due to 
moderating trend of domestic demand. Meanwhile, the positive sentiment on the improving Indonesia's economic fundamental impacted the increase of capital inflow in the form of both direct investment and portfolio investment. The increase of capital inflow, which in turn drove the capital and financial transactions, recorded surplus by USD 7.83 billion. The positive development on IBP's performance eventually contributed to the increasing foreign exchange reserve. In March 2014, Indonesia's foreign exchange reserve was recorded USD 102.6 billion, or was equal to 5.7 months of import and the government foreign debt settlement, above the international adequacy standard by 3 months of import.

The Rupiah's exchange rate performed the increasing trend in the quarter I 2014, along with the improving economic fundamental and IBP's performance. At the end of the quarter I 2014, Rupiah appreciated by $7.13 \%$ compared to the final level of 2013 . The appreciation had primarily occurred since February 2014 along with the increase of capital inflow. The Rupiah's appreciation was also accompanied by the decreasing volatility. Meanwhile, the micro structure of foreign exchange market performed a positive improvement. The increasing transaction volume of foreign exchange was sustained by the actively foreign exchange transaction and the smaller margin of Rupiah's bid-ask so that it performed the more liquid condition of foreign exchange market.

In the quarter I 2014, inflation development performed improvement to support the inflation achievement target by $\mathbf{4 . 5}+1 \%$ in 2014 . Inflation was recorded $7.32 \%$ (yoy) in the quarter I 2014, much lower than the previous quarter that was $8.38 \%$ (yoy). The decrease of inflation was driven by the volatile food group and the core group. The decrease of inflation of volatile food group was driven by harvest on some commodities, even though it was momentarily disrupted by weather and natural disaster in the beginning of the year leading to the unstable production on some commodities. Meanwhile, the decrease of core inflation was sustained by the moderating economy, the minimizing external pressure, and the improving inflation expectation. Nevertheless, inflation on administered price group slightly increased by the increase of LPG $12 \mathrm{~kg}$ price and cigarette custom tariff, as well as the implementation of surcharge policy of aircraft tariff.

The manageable Indonesia's economic adjustment was sustained by the stable financial system. The development was sustained by the banking system resistance and the improving performance of financial market. The resistance of banking industry remained strong with the manageable credit risk, liquidity, and market, as well as the strong capital support. The growth of loan to the private sectors decreased from 21.4\% (yoy) on the quarter IV 2013 to 19.1\% (yoy) in the quarter I 2014, in accordance with moderating domestic demand. Meanwhile, the capital market performance also improved as reflected by the increasing trend of IHSG and decreasing yield of SBN. The improving performance of capital market was sustained by the increasing investor's optimism on domestic economy. 
The development of payment system was slowing down in the quarter I 2014 along with the moderating domestic economy. The average of distributed fiat money grew by $13.2 \%$ (yoy) in the quarter I 2014, decreased from the previous quarter by 13.4\% (yoy). It was driven by the decrease of money demand along with moderating economic growth. Besides, transaction volume of non-cash payment system was slowing down, even the value tended to be stable.

In the upcoming periods, economic stability is expected to be manageable and is sustained by the controlled economic adjustment. The economic growth of 2014 is expected to reach 5.1$5.5 \%$, much lower than the previous expectation by $5.5-5.9 \%$. The expectation was influenced by the unexpected export performance due to raw mineral export restriction policy as well as weaker economic growth of Tiongkok and global commodity prices than previously expected. In the beginning 2015, the economic growth is expected to improve by $5.4-5.8 \%$, even it is much lower than the previous expectation by $5.8-6.2 \%$. Inflation is expected to be lower than inflation in 2013 and range about $4.5+1 \%$ in 2014. In 2015, measurable monetary policy supported by the government policy is expected to be able to decrease inflation by $4.0+1 \%$.

Some of the risks potentially increase the pressure on economic stability and disrupt the effort on reducing current account deficit to the healthier level require a serious concern. From the global perspective, risks relate to the potential decrease of commodity prices and the slowing down growth of Tiongkok economy potentially increases the current account deficit. The risk of uncertainty on The Fed policy normalization also got a serious concern as it potentially disrupts the prospect of foreign investment. Domestically, the most concern-required aspect is the potential of price pressure regarding the adjustment pressure of the administered price and the increase of food price as delaying impact of flood and the impact of El Nino leading to dry season in some regions. 
294 Bulletin of Monetary, Economics and Banking, Volume 16, Number 4, April 2014

This page intentionally left blank 